\title{
ABUNDANCE INDICES OF SKIPJACK TUNA (Katsuwonus pelamis) FROM THE INDONESIAN DRIFTING GILLNET FISHERY IN THE INDIAN OCEAN
}

\author{
Dian Novianto $^{1 *}$, Ilham ${ }^{2}$, Bram Setyadji ${ }^{3}$, Chandara Nainggolan ${ }^{2}$, Djodjo Suwardjo $^{2}$, Suciadi \\ Catur Nugroho $^{3}$, Syarif Syamsuddin ${ }^{2}$, Arief Efendi ${ }^{2}$, Yaser Krisnafi ${ }^{2}$, Muhamad Handri ${ }^{2}$, Abdul \\ Basith $^{2}$, Yusrizal ${ }^{2}$, Erick Nugraha ${ }^{2}$. \\ ${ }^{1}$ Marine Research Center, Agency for Marine Affairs \& Fisheries Research \& Human Resources, \\ Ministry of Marine Affairs \& Fisheries Republic of Indonesia. \\ ${ }^{2}$ Department Fishing Technology, Faculty Fishing Technology, Jakarta Fisheries University, Jakarta, Indonesia \\ Ministry of Marine Affairs \& Fisheries Republic of Indonesia; \\ ${ }^{3}$ Research Institute for Tuna Fisheries, Agency for Marine Affairs \& Fisheries Research \& Human Resources, \\ Ministry of Marine Affairs \& Fisheries Republic of Indonesia; \\ * Correspondence: dianovianto78@gmail.com; Tel.: +62-812-293-2344
}

\begin{abstract}
Skipjack tuna supports a valuable commercial fishery in Indonesia. Skipjack tuna are exploited in the Indian and Pacific Oceans with a variety of gear but drifting gillnets are a common method used by Indonesian fishers. However, despite of its importance, little information on the drifting gillnet fishery is available. This study describes a preliminary examination of the catch and effort data from the Indonesian skipjack drifting gillnet fishery. Utilizing daily landing report from 2010-2015, nominal catch per unit of effort (CPUE) data were calculated as $\mathrm{kg} /$ day at sea. Generalized Linear Models (GLM) were used to standardize the CPUE, using year, quarter, day at sea, and area as fixed variables. Model Goodness-of-fit and model comparison was carried out with the Akaike Information Criteria (AIC), the pseudo coefficient of determination $\left(R^{2}\right)$ and model validation with a residual analysis. The final estimation of abundance indices was calculated by least square means (LSMeans) or Marginal Means. The results showed that days accounted for most of the variation in CPUE, followed by year, quarter, and area. In general, there were no noticeable trends indicative of over exploitation or population depletion suggesting a sustainable fishery for Skipjack tuna in Indonesian waters.
\end{abstract}

Keywords: abundance indices; skipjack tuna; drifting gillnet; Indian Ocean 


\section{Introduction}

Skipjack tuna (Katsuwonus pelamis), are commercially valuable and exploited by coastal countries along the Indian and the Pacific Ocean. In Indonesia, as for other countries that target skipjack tuna, the fishery uses purse seine, drifting gillnet, handline, troll line and pole and line. The average catch of tunas Indonesian from 2011 to 2015 from Indian Ocean region was estimated to be $133,092 \mathrm{t}$, where the proportion average catch was dominated by skipjack tuna $(49.79 \%)$, yellowfin tuna (26.53\%), bigeye tuna (18.14\%) and albacore tuna (5.53\%) [1]. Catches of skipjack from Indonesian fleets are increasing over the years, whereas a declining trend of skipjack catch per unit effort (CPUE) was reported by the French purse seine fleets [2]. Drifting gillnets is an important method for catching skipjack in Indonesian waters. Fishing operations involving gillnets contribute about $35 \%$ of the reported catch from the Indian Ocean Tuna Commission (IOTC), is not solely arises as the most important single fishing gear in terms of volume of catches but the presence of gillnet catches shows a growing tendency compared to other fishing gear [3].

Most stock assessments currently carried out for tuna are based on fishery-dependent data [4]. Data are gathered from the commercial fisheries and analyzedas catch per unit of effort (CPUE, either in number or biomass). It is important to standardize CPUE data to account for sources of variation other than abundance of the stock [5-6].

In this study we evaluate the fishing patterns of the drifting gillnet fishery in the coastal Southern Java areas using standardized CPUE indices. By standardizing the CPUEs for skipjack, the effects of the covariates considered are removed from the annual CPUE values, and those standardized CPUEs can be used as annual indexes of abundance indices [4].

\section{Results}

\subsection{Spatial distribution of the data}

A total of 4,601 catch and effort data of drifting gillnet fleets was obtained from daily landing activity from January 2010 to December 2015. The number of successful trips was 4,486 (97.51\%) and the percentage of zero catch per trip around $2.49 \%$ (115 trips). The spatial distribution of the effort is represented in 1x1 degree blocks with darker and lighter colors representing respectively to areas with more and less effort in day at sea (Figure 1). For CPUE standardization, spatial/area effects were assessed from data derived by $2 \times 2$ degree blocks (fishing grounds identified from skipper interviews representing the traditional name of the fishing ground area: Pangandaran, 
Cimiring, Ciamis, Palabuhan Ratu, Kebumen, Gombong, Yogyakarta, Ujung Kulon, Prigi, Pamengpeuk, and Srandil).

Fishing effort was more concentrated in area 3 near the coastal area, namely Srandil, Kebumen, Gombong, Yogyakarta (darker color), followed by Palabuhanratu, Pangandaran, Cimiring and Ciamis (lighter colors) and less effort occurred in the offshore area (area 4,5,6,7).

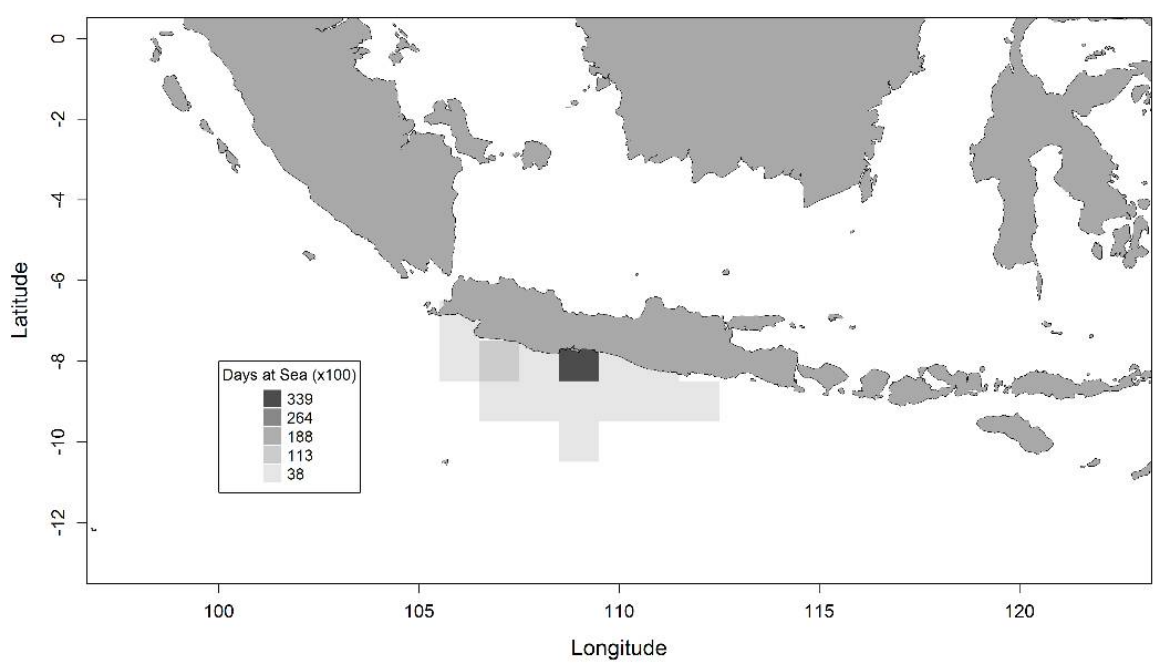

Figure 1. Distribution of drifting gillnet fishery sets data used in this skipjack CPUE standardization. The effort is represented in $1 \mathrm{x} 1$ degree blocks with darker and lighter colors representing respectively to areas with more and less effort in days at sea.

\subsection{CPUE data characteristics}

The nominal time series of the skipjack CPUE is presented in Figure 3. In general, the series was highly variable, with minimum CPUE in 2010 (41.3 kg/days at sea) and peaks in 2012 (208.2 $\mathrm{kg}$ /days at sea) and lower values in the remaining years. The percentage of fishing sets with zero catches of skipjack was generally low (2.49\%) but more frequent in 2010 than in other years. Nominal CPUE distribution was highly skewed necessitating log-transformation (Figure 2) 

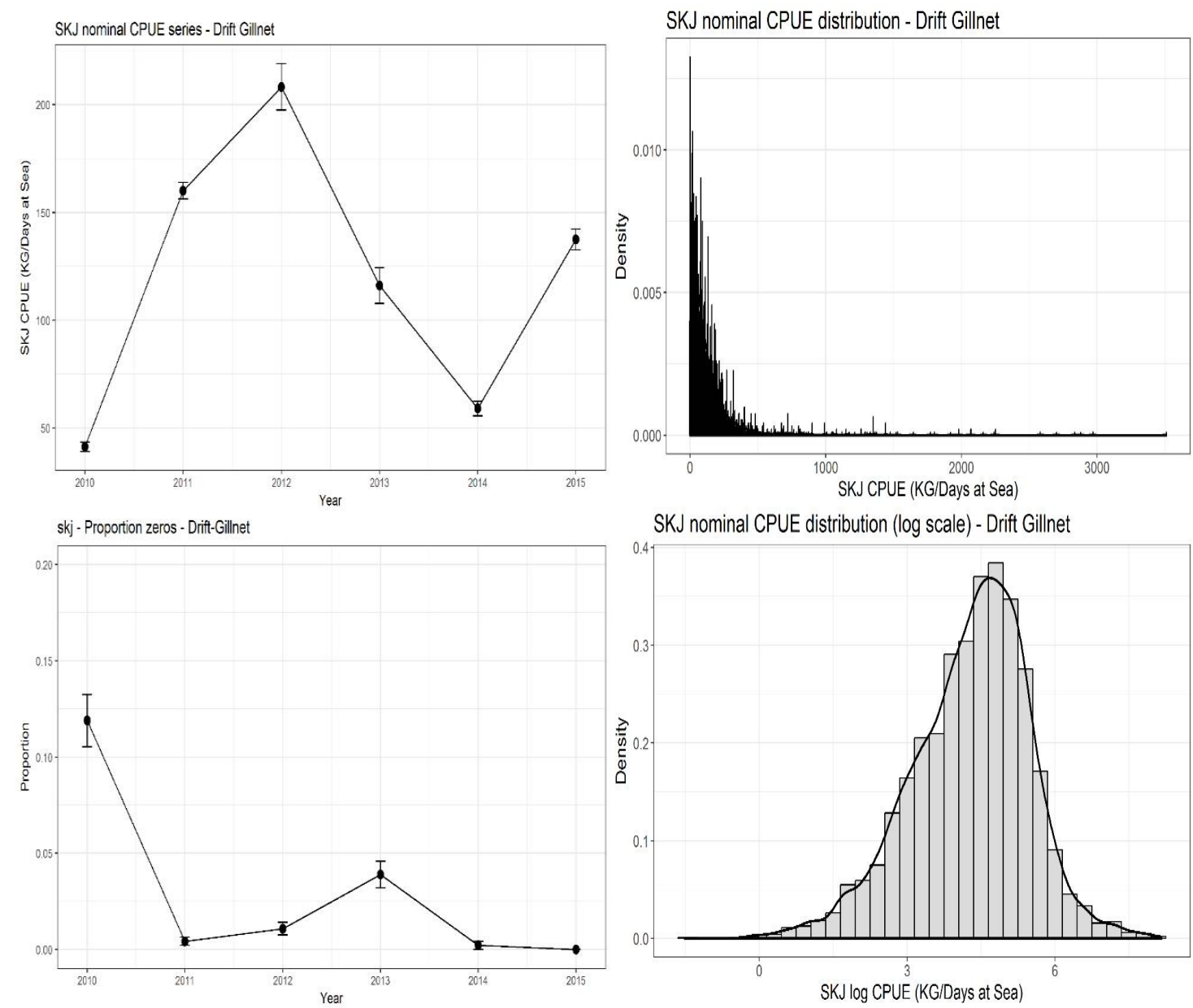

Figure 2. Nominal CPUE series (kg/Days at sea) forskipjack in the Indonesian drifting gillnet fishery data between 2010 and 2015 (top-right). Proportion of zero catches by trips and per year between 2010 and 2015 (bottom-right). Data are means with SE. (Top-left) Distribution of the nominal skipjack CPUE from the gillnet data in non-transformed and log-transformed (bottom-left) scales.

\subsection{CPUE standardization}

Several explanatory variables tested for the skipjack CPUE standardization were significant sources of variation. Some interactions were also significant and were therefore included in the final model. For the final model, factors that accounted for most of the variation were days, followed by year, quarter, area, and then the other effects and the interactions (Table 1).

Table 1. Deviance table of the parameters used for the skipjack CPUE standardizations using a Tweedie GLM with link=log. For each parameter the degrees of freedom (Df), the deviance (Dev), the residual degrees of freedom (Resid Df), the residual deviance (Resid. Dev), the F-test statistic and the significance (p-value) are shown. 


\begin{tabular}{lrrrrrr}
\hline \multicolumn{1}{c}{ Parameter } & Df & Dev. & $\begin{array}{c}\text { Resid. } \\
\text { Df }\end{array}$ & $\begin{array}{c}\text { Resid. } \\
\text { Dev. }\end{array}$ & F-stat. & p-value \\
\hline (Intercept only) & & & 4599 & 19532 & & \\
Year & 5 & 3151.5 & 4594 & 16380 & 202.60 & $<0,001$ \\
Quarter & 3 & 429.1 & 4591 & 15951 & 45.98 & $<0.001$ \\
GT & 1 & 31.7 & 4590 & 15920 & 10.18 & $<0.01$ \\
Days & 1 & 3173.6 & 4589 & 12746 & 1020.10 & $<0.001$ \\
Area & 6 & 133.6 & 4583 & 12612 & 7.16 & $<0.001$ \\
Quarter:GT & 3 & 1.9 & 4580 & 12610 & 0.21 & $0.89 \mathrm{NS}$ \\
Quarter:Days & 3 & 113.3 & 4577 & 12497 & 12.14 & $<0.001$ \\
GT:Days & 1 & 3.4 & 4576 & 12494 & 1.09 & $0.30 \mathrm{NS}$ \\
GT:Area & 4 & 83.2 & 4572 & 12411 & 6.69 & $<0.001$ \\
\hline
\end{tabular}

In terms of model validation, the residual analysis, including the residuals distribution along the fitted values, the QQ plots, and the residuals histograms, it was possible to detect the presence of some outliers. Residual analysis, (Figure 3) showed that the model was adequate with no major outliers or trends.
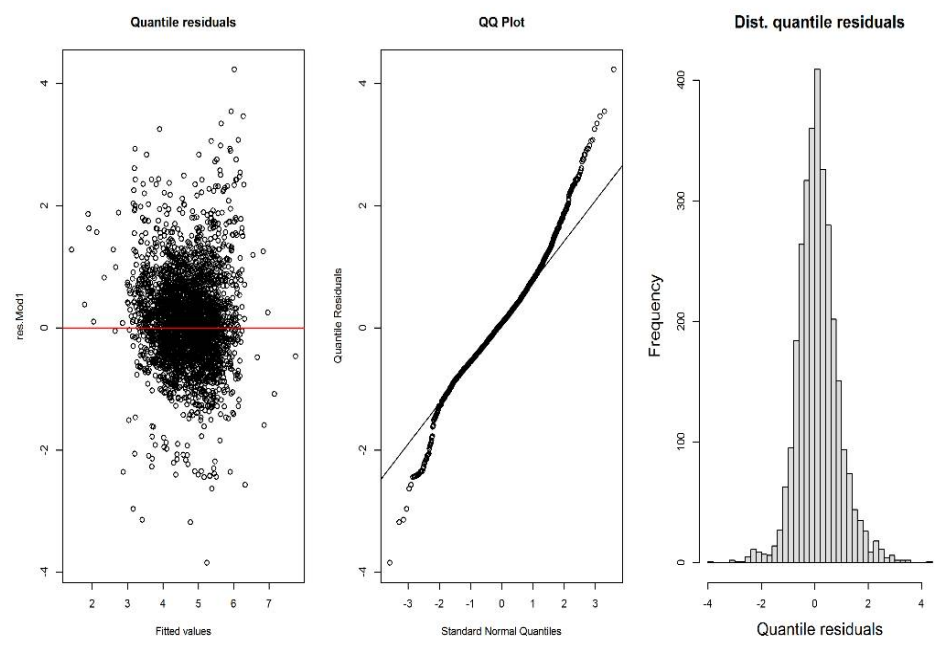

Figure 3. Residual analysis for the final skipjack CPUE standardization model for Gillnet data between 2010 and 2015. Plots presented include the histogram of the distribution of the residuals (right), the QQPlot (middle) and the residuals along the fitted values on the log scale (left).

The final nominal and standardized skipjack CPUE index (kg/Days at sea) for the drifting gillnet fishery are shown in Figure 4 and Table 2. The trends were similar to the nominal series, 
but with smoother peaks in 2012. In general, there were no noticeable trends, with the series varying along the period.

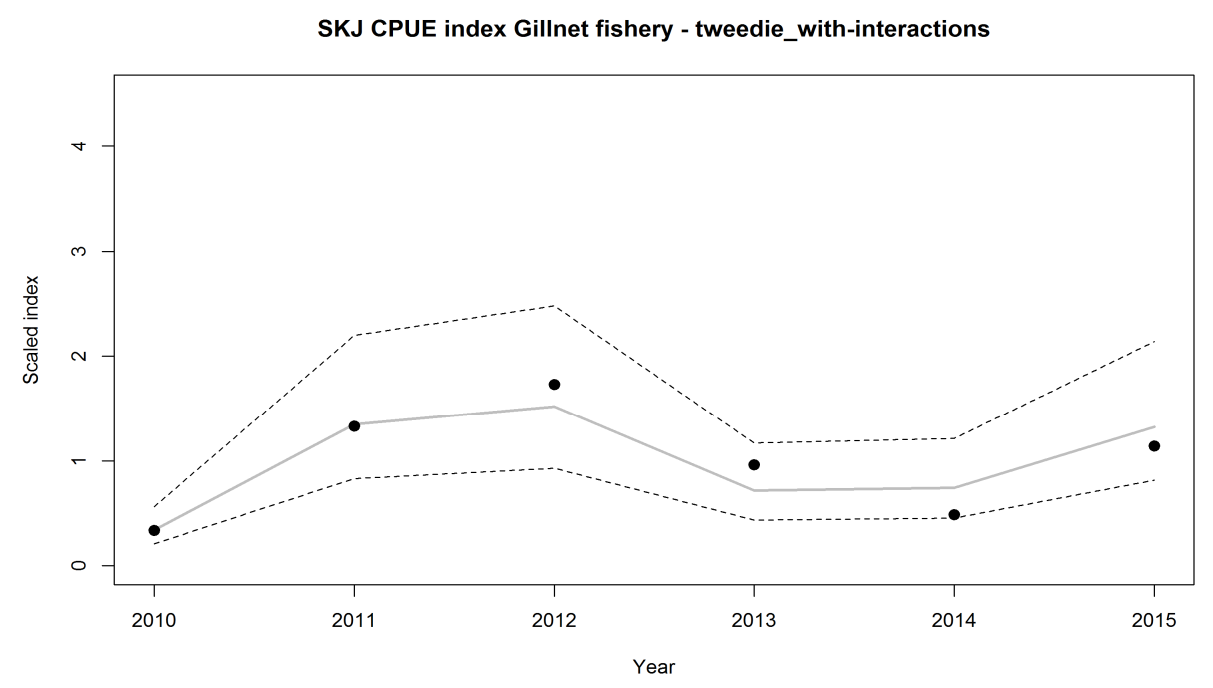

Figure 4. Scaled standardized CPUE series for skipjack from drifting gillnet data using a tweedie model, between 2010 and 2015. The solid lines refer to the standardized index with the $95 \%$ confidence intervals, and the dots represent the nominal CPUE series. Both series are scaled by their means.

Table 2. Nominal and standardized CPUEs (kg/Days at sea) for skipjack from the Indonesian drifting gillnet fishery. The point estimates, 95\% confidence intervals of the standardized index are presented, as well as the nominal CPUE values.

\begin{tabular}{ccccc}
\hline \multirow{2}{*}{ Year } & \multirow{2}{*}{$\begin{array}{c}\text { Nominal } \\
\text { CPUE }\end{array}$} & \multicolumn{3}{c}{ Standardized CPUE index (kg/Days at sea) } \\
\cline { 3 - 5 } & & Stdz CPUE & Lower CI (25\%) & Upper CI (95\%) \\
\hline 2010 & 41.29 & 27.94 & 0.21 & 0.57 \\
2011 & 160.08 & 108.72 & 0.83 & 2.20 \\
2012 & 208.21 & 122.29 & 0.93 & 2.47 \\
2013 & 116.1 & 57.84 & 0.44 & 1.17 \\
2014 & 58.99 & 59.90 & 0.46 & 1.21 \\
2015 & 137.49 & 106.41 & 0.82 & 2.14 \\
\hline
\end{tabular}

\section{DISCUSSION}

Skipjack is the main target species for the drifting gillnet fishery in Cilacap, and thus the number of zero catch per set was very small (2.49\%). It is also a statement that this gear is effective in term of catching this particular species. For data where the number of zero catches per set is 
small, models with a gamma distribution are generally suitable [7]. Tweedie model is usually use for dataset which contain a lot of zeros [8-9], but actually it can be used for modelling the dataset with numerous kind of distribution. This is possible because tweedie model have wide range of distribution (usually written as $p$ ), from normal, poisson, gamma and inverse gaussian [10].

Variable including days, year, quarter, area (FMA 573) as well as $2^{\circ} \times 2^{\circ}$ degree blocks (Southern of Java coastal region) were shown to have a significant effect on skipjack catch rates. The interaction between the quarter and days reflects the observed concentration of fishing effort in area 3 (Srandil, Kebumen, Gombong, Yogyakarta). The drifting gillnet fleets operating from Cilacap have a similar spatial distribution throughout the year [11]. Furthermore, they revealed that since 2010 drifting gillnets operated mostly in inshore waters because purse seiner fleets deploy FADs in traditional gillnet fishing grounds located offshore.

The final model showed that days is an important source of variation in skipjack CPUE. Usually, trip duration is 10-15 days with effective days 8-12 for fleets without refrigeration. More recently, vessels with refrigeration can extend fishing days to 30-45 days/trip [12]. Changes in fishing patterns can also occur when targeting other species such as bigeye and yellowfin tuna particularly during July-August [13]. The low skipjack catches recorded in 2010 were similar to the low catches of shark at the same period, although overfishing may be a factor, low catches are more likely to reflect a substantial reduction in effort because of a $33 \%$ increase in fuel prices. The fuel-price increase, a consequence of the partial elimination of fuel subsidies by the government, resulted in many tuna fishing companies reducing fishing operations in 2010 [14].

Based on final analysis skipjack CPUE index drifting gillnet fishery showed stable pattern, it's mean skipjack tuna stock is not in the threatened condition, but the reported decreasing catch in recent years should be an early warning for this fishery [15]. Although the results here presented should be considered preliminary, this study provides preliminary insights into the relationship between catch rates of skipjack and related fishing patterns. Such information will be important in future management of this important fishery.

\section{Materials and Methods}

\subsection{Study area}

The Area of study is located in the southern part of Java waters of eastern Indian Ocean between $7^{\circ}-11^{\circ} \mathrm{S}$ and $105^{\circ} \mathrm{E}-113^{\circ} \mathrm{E}$ and located in fisheries management area 573 southern 
of Java coastal region (Figure 5). The fishing ground area is noted on the form that records fishing vessel production at fishery port/fish landing site. The form used to records all landed catches (usually called SL3 form) based on date of landing, fishing gear, ship size, ship category; capture or carrier, trip duration, number of crew, as well as the area of fishing operations) collected by officer of Cilacap Ocean Fishing Port (OFP). The fishing ground area of drifting gillnet sets was classified into several categories (according to the geographical position by name of city in southern Java coastal area, e.g; Pangandaran, Palabuhan Ratu, Yogyakarta). Furthermore, the drifting gillnet sets were also classified into 7 different area definitions ( $2 \times 2$ degree blocks) for use in the skipjack CPUE standardization model (Figure 6).

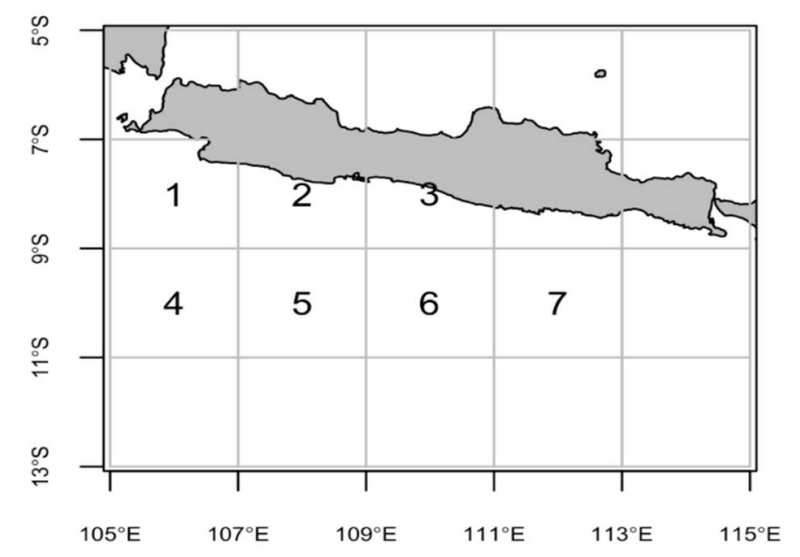

Figure 6. Fishing ground area of drifting gillnet fishery in $2 \times 2$ degree blocks.

\subsection{Fishery data}

Fishers are required to record all landed catches including date of landing, fishing gear, ship size, ship category; capture or carrier, trip duration, and number of crew. These data are collected by officers of the Cilacap Ocean Fishing Port (OFP). The unit of effort drifting gillnet fleets "days at sea", while catches are in weight $(\mathrm{kg})$. A total of 4,601 catch and effort data of drifting gillnet fleets were obtained from daily landing activity from January 2010 to December 2015. The number of successful trips was 4,486 (97.51\%) and the percentage of zero catch per trip around $2.49 \%$ (115 trips).

\subsection{CPUE standardization}

Effort was defined as the days at sea (including the time spent to the fishing ground and back). For CPUE standardization, the response variable was catch per unit of effort (CPUE), 
measured as weight $(\mathrm{kg})$ per days at sea (days). The standardized CPUEs were estimated with Generalized Linear Models (GLMs).

For this model, the nominal CPUE was used directly in the response variable given this specific characteristic of the distribution. The covariates considered and tested in the models were:

- Year: analyzed between 2010 and 2015;

- Quarter of the year: 4 categories: $1=$ January to March, $2=$ April to June, $3=$ July to September, 4 = October to December;

- Operational characteristics of the fishery, which can be used as proxies for targeting effects: vessel size (gross ton), day at sea (trip duration) and area fishing ground $(2 \times 2$ degree blocks)

The significance of the explanatory variables in the CPUE standardization models was assessed by likelihood ratio tests (ANOVA test) comparing each univariate model to the null model and by analyzing the deviance explained by each covariate. Goodness-of-fit and model comparison was carried out with the Akaike Information Criteria (AIC) and the pseudo coefficient of determination $\left(\mathrm{R}^{2}\right)$. Interactions were considered and tested, and the significant interactions were used in the analysis. Model validation was carried out with a residual analysis. The final estimated indices of abundance were calculated by least square means (LSMeans) or Marginal Means. For comparison purposes these were scaled by the mean standardized CPUE in the time series. Statistical analysis was undertaken with R Project for Statistical Computing version 3.2.0 [16], using several additional libraries [17-26].

\section{Conclusion}

The final model, the factors that contributed most for the deviance were the days, followed by year, quarter, area, and then the other effects and the interactions. The trends of abundance indices were relatively similar to the nominal series with smoother peaks. Stable pattern of the standardized CPUE series showed that skipjack tuna stock is not in the threatened condition, 
Acknowledgement: We would like to thank head office of Cilacap Ocean Fishing Port., Central of Java, Indonesia for providing fisheries data, we thank to United Nations Industrial Development Organization (UNIDO) for financial support. We would like to express appreciations Dr. Paul McShane, Monash University, Australia for valuable advice and comment. We also gratefully acknowledge Dr. Rui Coelho, Portuguese Institute for the Ocean and Atmosphere for advising statistic analysis.

Author Contributions: Dian Novianto designed and performed the experiment, analyzed the data, and wrote the paper. Ilham., Bram Setyadji., Chandara Nainggolan., they also designed the experiment and analyzed the data. Djodjo Suwardjo., Suciadi Catur Nugroho., Syarif Syamsuddin., Arief Efendi., Yaser Krisnafi., Muhamad Handri., Abdul Basith., Yusrizal., Erick Nugraha. They collect and tabulate fishery data.

Conflicts of Interest: The authors declare no conflict of interest.

\section{Reference}

1. Irianto, H.E.; Wudianto.; Fahmi, Z.; Setyadji, B.; Satria, F.; Sadiyah, L.; Nugraha, B.; Widodo, A.A. Indonesia national report to the scientific committee of Indian Ocean Tuna Commission. Available online: http://www.iotc.org/sites/default/files/documents /2016/11/IOTC-2016-SC19-NR10 - Indonesia.pdf. (accessed on 1 December 2017).

2. Marsac, F.; Floch, L. Skipjack tuna CPUE trends using alternative indices from the French purse seine logbooks. 2014. Available online: http://www.iotc.org/fr/documents/ skipjack -tuna-cpue-trends-using-alternative-indices-french-purse-seine-logbooks. (accessed on 5 December 2017).

3. Aranda, M. Description of tuna gillnet capacity and bycatch in the IOTC Convention Area. 2017. Available online: http://www.iotc.org/documents/description-tuna-gillnet-capacityand-bycatch-iotc-convention-area. (accessed on 1 November 2017).

4. Coelho, R., Santos, M.N and Lino, P.G. 2016. Standardized cpue of blue shark in the Portuguese pelagic longline fleet operating in the North Atlantic. Collect. Vol. Sci. Pap. ICCAT, 72(4): 1044-1066.

5. Ramos-Cartelle, A., García-Cortés, B., Fernández-Costa, J and Mejuto, J. 2016. Standardized catch rates in biomass for the blue shark (Prionace glauca) caught by the Spanish longline fleet in the South Atlantic during the period 1997-2013.Collect. Vol. Sci. Pap. ICCAT, 72(5):1092-1100.

6. Maunder, M. N., Punt, A. E. 2004. Standardizing catch and effort data: a review of recent approaches. Fish. Research 70. 141-159. DOI: 10.1016/j.fishres.2004.08.002.

7. Andrade, H.A. 2008. Catch rate for the skipjack tuna (Katsuwonus pelamis) in the southwest of the South Atlantic Ocean (in Portuguese). B. Inst. Pesca, São Paulo,34 (3): $391-402$.

8. Sadiyah, L., Dowling, N and Prisantoso, B.I. 2012. Developing recommendations for undertaking cpue standardisation using observer program data. Ind.Fish.Res.J. 18(1): 1933. 
9. Candy, S.G. 2004. Modeling catch and effort data using generalized linear models, the Tweedie distribution, random vessel effects and random stratum-by-year effects. CCAMLR Science 11, 59-80.

10. Shono, H. 2008. Application of the Tweedie distribution to zero-catch data in CPUE analysis. Fisheries Research 93 (2008): 154-162. DOI: 10.1016/j.fishres.2008.03.006.

11. Widodo, A.A, F.Satria, L.Sadiyah \& J. Riyanto, 2011. Neritic tuna species caught by drifting gillnet in Indian Ocean based at Cilacap-Indonesia. IOTC-2011-WPNT01-21 Rev_2. 19pp.

12. Novianto, D., Nugroho, S. C., Tampubolon, P. A. R. P. 2016.Catch composition of gillnet fishery base on oceanic fishing port Cilacap. Proceeding fish national symposium. Ichtiology of Indonesian society. Jakarta 4 May 2016. Book II : 855-865. (in Bahasa).

13. Novianto, D., Nugroho, A. F., Zedta, R. R. 2016. Composition and abundance of pelagic shark caught by drifting gillnet in Cilacap oceanic fishing port, Indonesia. IOTC-2016WPEB12-17. 16pp.

14. Fahmi \& Dharmadi (2015) Pelagic shark fisheries of Indonesia's Eastern Indian Ocean Fisheries Management Region, African Journal of Marine Science, 37:2, 259-265, DOI: 10.2989/1814232X.2015.1044908.

15. Indian Ocean Tuna Commission [IOTC]. 2016. Report of the 18th Session of the IOTC Working Party on Tropical Tunas. Seychelles, 5-10 November 2016. IOTC-2016WPTT18-R[E]. $126 \mathrm{pp}$.

16. R Core Team. 2016. R: A language and environment for statistical computing. $\mathrm{R}$ Foundation for Statistical Computing, Vienna, Austria. URL http://www.R-project.org/.

17. Venables, W.N., Ripley, B.D. 2002. Modern Applied Statistics with S. 4th Edition. Springer, New York.

18. Wickham, H. 2007. Reshaping data with the reshape package. J. Stat. Softw., 21(12):1-20.

19. Wickham, H. 2009. ggplot2: elegant graphics for data analysis. Springer, New York.

20. Fox, J., Weisberg, S. 2011. An $\{\mathrm{R}\}$ Companion to Applied Regression, 2nd Edition. Sage, Thousand Oaks CA.

21. Gross, J, Ligges, U. 2012. Nortest: tests for normality. R package version 1.0-2. http://CRAN.R-project.org/package=nortest.

22. Becker, R.A., Wilks, A.R., Brownrigg, R., Minka, T.P. 2013. Maps: draw geographical maps, R package version 2.3-6. http://CRAN.R-project.org/package=maps.

23. Bivand, R., Lewin-Koh, N. 2013. Maptools: tools for reading and handling spatial objects. R package version 0.8-27. http://CRAN.R-project.org/package=maptools.

24. Dunn, P.K. 2013. Ttweedie: Tweedie exponential family models. R package version 2.1.7.

25. Stabler, B. 2013. Shapefiles: read and write ESRI shapefiles. R package version 0.7. http://CRAN.R-project.org/package=shapefiles.

26. Lenth, R.V. 2014. lsmeans: least-squares means. R package version 2.11. http://CRAN.Rproject.org/package $=$ lsmeans. 